\title{
Urgences
}

\section{Une allée...}

\section{Louise Beauchamp}

Numéro 13, mars 1986

\section{Éclats d'atelier}

URI : https://id.erudit.org/iderudit/025214ar

DOI : https://doi.org/10.7202/025214ar

Aller au sommaire du numéro

\section{Éditeur(s)}

Urgences

\section{ISSN}

0226-9554 (imprimé)

1927-3924 (numérique)

Découvrir la revue

\section{Citer ce document}

Beauchamp, L. (1986). Une allée... Urgences, (13), 36-36.

https://doi.org/10.7202/025214ar d'utilisation que vous pouvez consulter en ligne.

https://apropos.erudit.org/fr/usagers/politique-dutilisation/ 


\section{Louise Beauchamp}

Une allée royale. Des lunes qui lamentablement traversent le grain du sable orange. Elles, illégitimement mortes à Tokyo, paraissent sous la lampe faible, noires et folles. Les mains, décrivant le démon, caressent les peurs. Larme, pluie sur les corps, verre sous les pieds.

Une fille cassée, drame de séduire. Fourvoyons-nous devant les rouges croix scandaleusement riches. Incidemment, Hantée Crise limoge le paumé.

La radio, comme toujours, froide, habile songe, martèle de bruit, salive de blues. Des lieux prolongent l'ennui. Des films m'arrachent en blocs, m'étranglent. Ah! tout connaître et s'empaler soi-même.

Assommer, tout au moins empêcher la folle toute en vitre de draps, garce jazzée, épicée, d'harceler n'importe où: des caves basses du Népal à la ville cassée de Paris.

En fleur ou tissu des sangs, les mites suaves galopent à l'étage pour racoler.

Tachée parce qu'on la ligote, brisée de supplier, Hantée Crise ainsi qu'une larve émane du stade foetal sans déranger ni la reine, ni I'homme défait par les mites. Je dessine l'arène triste: Hantée Crise faible, d'une croix cassée, désespérément sans pieds ni mains... sur l'allée royale. 